\title{
Interview Transcript of Black Music Matters and The Black Messiah Album:
}

\section{An Interview with Adrian Dunn}

\author{
Adrian Dunn ${ }^{1 *}$, Leah Gipson ${ }^{2}$, Marisol Norris ${ }^{3}$ \\ 1 Chicago College of Performing Arts, Roosevelt University, USA \\ 2 Art Therapy \& Counseling, School of the Art Institute of Chicago, USA \\ 3 Creative Arts Therapies \& Counseling, Drexel University, USA \\ *adrian.dunn@hoperaworld.com \\ Received: 28 January 2021 Accepted: 5 March 2021 Published: 20 April 2021 \\ Editor: Britton Williams
}

\begin{abstract}
In an audio interview, Adrian Dunn, discusses his album, The Black Messiah, with Leah Gipson and Marisol Norris. As a commentary on religious life in the U.S., the music was initially performed the year that Donald Trump was elected president in resistance to dominant, white Christian nationalism and hate speech. Dunn sought to preserve this history in an album. Dunn explains that The Black Messiah affirms Black liberation and justice, and situates responsibility with all persons as the work of a shared humanity. The discussion reflects on American musical traditions, narratives, Black spirituality, and an integral relationship between music and freedom.
\end{abstract}

Keywords: The Black Messiah Album, Adrian Dunn, The Adrian Dunn Singers, Black Music Matters

\section{Interview}

Audio: https://www.youtube.com/watch?v = FZwH-Ho2aCs

\section{Transcript}

Adrian Dunn: [...] these multiple identities that we bring to the table and oftentimes, I say as Black folks our bodies at one point were not our own, and I feel like we still feel those echoes of that post traumatic slave [pause] you know that whole thing is echoing day in and day out in so many of our experiences and it's very clear in our music that we produce, that we put out as Black folks in this country. If you're really listening, if you're really paying attention, it is very clear, you know, the state of where we are as folks, as well as Black artists. 
Leah Gipson: What you were saying about physically fighting for your life every day, and then having to come into a predominantly white space and have to justify your existence all the time by qualifying who you are and naming who you are knowing good and well people see you, right, and you have to say it to somehow soften it, or something like that. Make it more tolerable, make it more you know, I don't know, make it easier to be possessed.

Marisol Norris: And what that just kind of brings me back to [is] the opening, the first song where it says, I am the Black messiah, if you let me.

Adrian Dunn: yeah yeah that chorus, "they call me the Black messiah. I wear no chains, I bear no whips but I'll bear your pain. Call me the Black messiah dada dada dada dada dada hmm, if you let me dada dada dada dada dada. And what I always thought about was these naming of things as Leah just said, I got to be queer, I got to be Black, I gotta be this, I gotta be cis, I gotta be you know there's so many things. It can be overwhelming but, as I see it as an artist, and in my space and Black spaces, I'm Adrian.

I'm Adrian and I get to show up, and I see the Black messiah in a very similar thing, is to say that. That mentality, that heart, that spirit that flows through the music is the idea of liberation and peace and the things that we need to succeed, to have wholeness. And when I say I am the Black messiah, a number of my white colleagues said, "Adrian, I think this is a problem. You're saying you're Jesus. This is a problem. I don't know that this is a great idea, and that people are going to understand it," etc. But the reality is that no, I know what I mean. I know that what I'm saying is that the Black messiah is a mentality. It is Black liberation, it is pro Black, it is not anti-Black, it cannot be, and so again embracing those things and saying that, giving that space to be.

To just be-free from gun violence, and narratives of violence, and narratives of this, and all of these things that are put on you as a Black man, a Black gay man. Or a Black person period. Black woman. Black trans woman. Black, whatever identifier that comes after Black, right. There's going to be so many things that are kind of put on you and that you're expected to wear. And when you don't wear them, in any space, there's some type of pushback. And so, that whole part about, not just the "if you let me," but that this is something that is personal, and it's something that we all have to do. It's the work of everyone, not just those of us who are Black, who are the oppressed, or have been historically. But, to say that if you let me, I will be there. You know what I mean? If you let me, and to see that from a religious standpoint as well, that we as Black folks, our definition of religion, whether we call ourselves Christian, COGIC, Pentecostal or whatever, when you talk to us about what we believe in, who we are, and all of those things, our ideas of god, I think, are far more expensive than we are often given credit for, as well, as I hope that is exhibited here in The Black Messiah as well.

Leah Gipson: I'd like to hear from you the history of The Black Messiah as an album.

Adrian Dunn: Yeah, so as an album it's a new thing. This is actually a performance we've done for the past four years, and actually the very first year we did it was the year that Donald J trump was elected President. I thought that it was critical, at that moment. I felt like so much of the Christian narrative and mass media was dominated by what I felt like was hate speech, right, or things that did not align with the Christ that I saw, the Black messiah. I felt like it was an important moment, not just in the life of the church, but in the life of these United States to release this work as a live performance work. And so we've done that, for the past three to four years. During 2021, I thought it would be an excellent idea to preserve that in the form of a digital album.

Marisol Norris: I'm thinking about how the work of The Black Messiah in relationship to this idea of Black music matters is also tethered to the range of liberatory struggle that 
exists within Black communities, and so I'm wondering about the overall construction, orchestration of this piece-how the various threads or the different ways in which music is composed in particular here, how [do] you see that playing out as possibly a form of resistance? Then also how is that connected to freedom dreaming within black communities, the actual composition and orchestration of the work?

Adrian Dunn: So, I think that the actual music or the mechanics, if you will, under the hood what's there is a real journey and kind of embracing of so many styles. Obviously The Black Messiah is rooted very much so in the gospel style. But, I also feel like, as you hear on the record, very strong overtones of jazz, very strong overtones of blues, and also overtones of what we would consider classical music in America. So, for example, in the piece The Black Messiah, the title piece, is the voice of Tony Famous (his stage name) and he is delivering this amazing rap verse in The Black Messiah. And it starts off with a very kind of operatic, kind of overtone or bugle call in the beginning of the piece, because I felt like these are things that we are as Black folks, as Black artists, as Black musicians. We are all these things. We are opera singers. We are conductors and orchestrators and all of these things. And so The Black Messiah really takes you through a journey, in a very dramatic way, I believe.

You hear also in The Black Messiah, a lot of call and response, right? These are very foundational pieces to Black music in the United States. Oftentimes, I hear colleagues say, "Well what is Black music and how can you say Black music is American? Or how can you say these things? I can say that for me, right, for Adrian Dunn, and my compositional idea, and the things that I'm trying to say in my work, is that we are everything. Not that we are this or that, but we are all of that, and more. And so in the musical identity of these pieces, as I pointed to in The Black Messiah where you'll hear these huge high C, high D soprano obbligatos, then also in Rejoice, you'll hear those same overtones, but contrasting that with a piece like Rize Up, where this is the language of resistance. And when I say the language, I mean not just the actual words that are spoken, or the lyrics, but I'm talking about the musical vocabulary as well, which is very important in this conversation. So in a song like Rize Up the entire band is live, right? That's an important piece. Everyone that you hear on that piece is a human being playing an instrument. It's very much so a part of the Black art aesthetic, as I see it. At the end of Rize Up, also the chromatic passages that lead us to the build up at the very end of the storytelling in both rap verses as well.

One of my favorite songs, though, if I may talk about, from The Black Messiah-love The Black Messiah, of course, the title song-but I also really love the song Wonderful. This is based on the text, for unto a child is born, because I believe so very much that in the academy, right now, particularly in music criticism, and particularly in the kind of western Eurocentric music spaces, we are not really as Black artists encouraged to use our own music and our own expressions unapologetically. Gospel music has, in my opinion, continuously been treated as a stepchild of America, as I like to see it. Even though we all know very well that the world over loves the gospel choir, loves gospel music. Every time we turn on an award show or the Oscars or whatever, there's a choir and primarily a gospel choir.

And so, I think that Wonderful, just for me, embodies not just the actual voices of the singers, you also hear and in a very virtuosic way in the mic toss at the end, really embodying everything that we are as Black folks-our brilliance, our genius, our virtuosity in regards to improvisation, as well our virtuosity in the ad lib and telling the story essentially off the top of our heads. And I don't mean that in a negative way, but in the most beautiful way that we do as Black folks.

Marisol Norris: A few things that come to mind right now-actually I would love for us to listen to Wonderful, just a brief moment of it. And can we talk about that and 
what's taking place in the music there, and maybe even think about how it's related to creativity in the arts therapies.

[song Wonderful plays]

\section{Lyrics}

For unto us, a son is given,

For unto us, a child is born

His name is wonderful, His name is counselor,

His name is everything, You are wonderful,

Counselor, prince of peace, mighty God.

(Your name is everything.)

Your name is wonderful, Wonderful counselor

Your name is prince of peace, You are a mighty God

We call him Jesus, His name is Jesus.

His name is Jesus, His name is Jesus.

\section{Video: https://youtu.be/MTCBInRxJMc}

Marisol Norris: We can keep on going, Adrian! We're over here (laughter). I don't know if you can see us. Both Leah and I are gone and my spirit is gone, and I could listen to more and more and more and more and oh. I need to take a moment, too, in the midst of this just thinking about the work that takes place in Black music that is so often contested, undermined, simplified, problematized. There's so many pieces that come to mind where in which we've been whitewashed, thought to not even elevate or adore repetition, and then all of a sudden in different fields and different disciplines, I think about music therapy, where repetition is the cornerstone for most improvisation. Thinking about the work and not only the work, but what is taking place in the music, that is the lifeblood, the lifestream; and thinking about how that can be, again, if taken out of context and taken out of the full authority of the music, how there's a violence that happens to the music outside of this context. And, I just want to acknowledge that reality and you saying Black music matters. I think about the violence that happens to Black music on a daily basis, and yet it rises above it and it contends with everything and still manages to do what it does and be what it is, you know? Thinking again also about how you've written about how the music is the Holy Spirit. I'm wondering how are all these pieces coming together for you? How do you see the music defined in this way, and what can you glean for us so that we are able to sit with the power and the fullness of what you're sharing?

Adrian Dunn: Thank you for, first of all, acknowledging that, because I believe, so much so, that my biggest issue with the academy oftentimes is the lack of acknowledgement, oftentimes in my space as a musician, of spirit. That Black music, particularly the music of the church, is something that is heavily rooted in the idea of spirit. And when you take, as you just said, when you take the music out of its intended context and its intended audience and its intended devices that we're using to deliver this, I feel like there's a lot of other things that then have to be explained when you are ignorant and don't understand those things.

It is being put back on the artists that we are somehow deficient, or we are somehow unaware of these things. It's like no, the reality is that our music is complex. It is very much so, in the way that I often talk about the spiritual, is the fact that there is sorrow. There is so much sorrow that it is unbearable and will take you out of here on any day. With a simple hum, will take you out of here. Okay? You don't even have to do the whole song. You don't have to [do] whatever. All you need to hear is a line, you know what I mean, of any spiritual, and I think what is important is that we are able to acknowledge so much that the music is healing in so many ways, because it's in its 
DNA. It's a part of what is our survival, as Black folks. [It] lives in our music. It lives in our expression. It lives in every fiber of who we are.

When we talk about a song like Wonderful that again, much like the spiritual takes the written, sacred, biblical texts, the KJV I call it, the King James version of the text, and uses that, but weaves it together, right, with all of these other elements that make the story plain and clear to us, who are Black folks that understand that particular type of, not just cultural expression, but musical elevation, and musical brilliance, and genius, and honor it. And honor it for all of those things. The complexity, again. The good in it. The bad in it. Everything. It's all wrapped up in there, you know what I mean? As opposed to parsing it out and so thank you for acknowledging that because it's something that I feel like The Black Messiah in and of itself is an act of resistance as a piece.

Us just putting this out to the world and saying to the world, as a classically trained musician. Some of my colleagues will listen to this and will go, "Well, you know that's easy." Or you know, "They're just hollering," or they're just whatever. I want to say, if that was the case, how many years has it been that y'all been trying to holler like us? How many times? How many years? How many white artists will you put in front of us that are singing our words, that are singing our melodies that are produced by us? Again white faces on Black music is problematic. So, somehow when we start to actually own and have agency over our own work, and when we're able to say that this is what it is on our terms and I'm not asking you. I'm not asking you for your permission. I'm not asking you for your blessing, because I don't need your blessing. The only blessing that I needed was from the creator and I already have that so, I'm done.

I'm here to say that my healing, my agency, who I am and why I write, and why I do the work that I do, hinges on who I am as a Black man in America period. Black music matters. Period. I matter. Period. If this is the language of healing and expression and liberation and the way in which I choose to tell it, well then I'm sorry if there are folks who may not understand it, but I challenge you to listen to more if you seek to find out.

Marisol Norris: I want to say one thing, and this is not to even contend or discredit what has already been said. But I think about recently there's this article, thinking about the tensions between, I want to say academic pursuit and intellectualization of this work. Because I also believe that this intellectualization and the synthesis of this work is happening in multiple places, but that academic pursuit like you mentioned is a different place. But there was a conversation about radical healing, what it takes up. And while you were speaking, these frameworks on radical healing for therapists that might not be linked or connected rather to the arts and the creative arts and expressive arts spaces was so profoundly articulated in what you said that it just spoke to me. Because, within this idea of radical healing, they're saying there needs to be two things that are occurring simultaneously. There has to be a hope and a freedom and a liberatory process that's taking place, and then also a recognition of the pain and the violence again that's taking place in the space. The way in which you talked about what was happening in that music amplifies that, but at the same time, I know it's the origin of that. I want to just thank you for sharing all of this because again we sometimes place emphasis in areas that emphasis doesn't need, and then we reduce and we don't really give weight to the types of work that's happening in so many spaces in Black music and Black culture.

Adrian Dunn: I definitely just wanted to say those things because I think where words fall short-I hate that expression sometimes but there's some truth to that-music is by design a sonic oration of your life, of our lives. As black folks, our lives are complex in so many ways, but our lives are beautiful and they deserve to be affirmed. Our music, all of it deserves to be affirmed, no matter whether or not you personally like it. I mean 
how many Bach motets and this, this, this do we have to see and hear to say I may not love it, but I gotta study it because it's y'all stuff?

But y'all don't study our stuff. But it's the only stuff that y'all continue to take from us on a consistent basis and tell us that our stuff is not good enough to be in your academies or the be on your concert stages, or to be anywhere else, or to be worthy enough to be in these spaces, where people who are committing terrorism against our own bodies and our own works and our own existence. And so I appreciate the opportunity to be able to speak, because that is how oftentimes our work as Black artists is reduced to nothing. Oftentimes in the Academy, I believe, and this is Adrian talking only Adrian talking, not just the deduction but the reduction because certain folks can't get their minds to a place of understanding, or expansion outside of how they see it.

That limits the contributions of people like myself to that structure, right? Because it's not delivered in those ways and in those confines. So, I appreciate this space, from the perspective of healing and understanding and acknowledging that so much of what we do as artists is intersectional, right? So much of what we do is not this over there, and that over here, but it's all of it together. So those experiences of healing that Black artists, musicians, that we've given the world. I'm overwhelmed when I think about not just the Jessye Normans and the Kathleen Battles, and the famous folks if you will. But when I think about the Nina Simones, and I think about the Billie Holidays, and I think about their stories that were not told, and how they died and how the government lied. When I think of the depths that folks have gone to, to lie on us as a people, and to discredit us as artists and musicians, my heart breaks. That is why I try so hard to continue to have my music represented in spaces and conversations like this. Because I hope that this is the only way that we can bring people aboard along on the fight of why Black music matters, and for this music to stand on its own, because it deserves to, even if it's not acknowledged by the Grammys. Even if it's not acknowledged by the establishment.

Leah Gipson: I do want to bring another context in for your work because your last point about Black artists and the treatment of Black artists, I think, speaks to something else that you bring to this conversation, not only as a composer and as an educator, who's constantly having to negotiate white spaces, you are also committed to creating those Black spaces. So, what we hear in the music, in terms of this commitment to Black music, is a commitment to Black spaces, right? And so, I wonder if you could just talk a little bit more about Black Music Matters, the community building that you're doing around mental health among Black artists as well.

Adrian Dunn: Absolutely. So last year I started an organization called Black Music Matters that works around advocacy for Black artists, particularly Black musicians. And I know very strongly in my heart not just that we need support and help, but also that we need advocates. We need people who will be true allies and who will support in the fight and so Black Music Matters has done, recently, a Black Music Matters Summit last year. We'll be doing our second summit this year in 2021 that covers a range of topics, including mental health, because that is something that is so critical and so important right now as it relates to all folks and particularly Black artists, that I think is kind of not getting as much play as it deserves at this particular moment.

Also, last week we premiered the new Rize Orchestra here, based in Chicago, Illinois. It is an all Black professional orchestra that is designed, where, if you are a Black player studying in any university program, you automatically have a spot in this orchestra. You are mentored by older Black players who are already in the game, already working in the industry. And you automatically, at 18 years old, can walk in and have a network of folks that it took me ten years to work on. That these young folks can come in and be mentored by older players and they also get a check as well, because the 
economics matter. They do. So I think part of community building... We are in partnership at Roosevelt University right now. We did our debut concert last week. It is free and on YouTube. If you want to check it out: Adrian Dunn and the Rize Orchestra (https://www.youtube.com/watch?v=GMHQzLTZY9w). The album comes out this Friday on Spotify as well as other digital outlets. It's Rize with a "Z" (RIZE). The Rize Orchestra.

The Adrian Dunn Singers as well ... I mean they're, they're amazing. That's who you heard. Yeah, those guys who were singing. They are just a blessing and they're a spectacular, all-professional group. Fifteen Black artists trained, both in the church, as well as in the academy. That can sing you into the ground, if it's a gospel song, or if it's an opera, whatever and so. What I appreciate about that is that we are helping to change that narrative by touring every year with the Redemption album, the spirituals that are dedicated to Black men and women murdered by police. Us touring that context and touring that piece and touring that record is helping us to reclaim the narrative that: number one, we're taking our stuff back, if it ever was confused about whose it was; but, also, that we are doing the work to make sure that we are performing for Black folks. That we are not just going into the main concert halls and the big stages, but that we are also doing the work to make sure that we are singing and making sure that this music, our music, our legacy, our story is preserved through performance as best we can, as well.

Everything we do also is 85 to 90 percent all Black produced-from writers to performers to engineers to graphic designers. All of those things because the business of music matters too, right. Who we're hiring behind the scenes and how we're able to make that happen and provide opportunities so that this music can continue to happen.

\section{About the authors}

Adrian Dunn is an accomplished singer, songwriter, and producer. Dunn holds a Bachelor of Music and Master of Music degree in Voice from The Music Conservatory at Roosevelt University with additional musical studies in opera at The Sibelius Academy of Music in Finland. Dunn is faculty at Roosevelt University, and Advisor for Racial Equity and Minority Student Success in the Chicago College of Performing Arts (CCPA). He has sung with the Chicago Symphony Chorus, Grant Park Symphony Chorus, Blossom Festival Chorus, and as a soloist with the North Shore Choral Society. Dunn has sung in the CCM Spoleto Opera Festival in Spoleto, Italy and is a frequent soloist in Handel's Messiah. He served as the opera chorus master for the midwest premiere of the opera Harriet Tubman-When I Crossed That Line to Freedom (2016) with the South Shore Opera Company of Chicago, and sang the lead role in the Chicago premiere of the Paul Laurence Dunbar opera The Poet (2017).

Leah Gipson is Assistant Professor in the Art Therapy and Counseling Department at the School of the Art Institute of Chicago (SAIC). She is a registered and board-certified art therapist (ATR-BC), and a licensed clinical professional counselor (LCPC) in Illinois, with a Master of Theological Studies. Leah is a board member for A Long Walk Home, an organization that uses the arts to empower young people to end violence against girls and women. She is also a board member of Praxis, an organization that provides affordable, democratically managed housing to individuals and families involved in social justice movement building. She is a co-founder of the BIPOC Student Fund by Black Arts Therapy Educators and an organizing member of the Critical Pedagogy in the Arts Therapies Alliance, formed in 2018.

Marisol Norris, $\mathrm{PhD}$, is a music therapist, critical arts therapies educator, cultural worker, and the founder of the Black Music Therapy Network, Inc. Her music therapy practice and supervisory experience have spanned medical and community health set- 
tings and include music therapy with adolescents experiencing housing insecurity, adults with psychiatric and dual diagnoses, families within the city court system and medically fragile children. These experiences have profoundly contributed to her multicultural relational lens and her dedication to fostering culturally sustaining, liberatory frameworks in music therapy education and practice. Her teaching and cultural work is an extension of a broader commitment to healing justice and dismantling relational and structural violence through community-based advocacy, education, and action. 